\title{
Feeding by common heterotrophic protists on the phototrophic dinoflagellate Biecheleriopsis adriatica (Suessiaceae) compared to that of other suessioid dinoflagellates
}

\author{
Hee Chang Kang ${ }^{1}$, Hae Jin Jeong ${ }^{1,2, *}$, Se Hyeon Jang ${ }^{1}$ and Kyung Ha Lee ${ }^{1}$ \\ ${ }^{1}$ School of Earth and Environmental Sciences, College of Natural Sciences, Seoul National University, Seoul 08826, Korea \\ ${ }^{2}$ Advanced Institutes of Convergence Technology, Suwon 16229, Korea
}

The species in the dinoflagellate order Suessiales have 5-24 latitudinal paraplate series and include many fossil and extant species. There have been a few studies on the ecophysiology of the phototrophic species Biecheleriopsis adriatica, and no study on its predators. Thus, we explored the feeding occurrence by common heterotrophic protists on B. adriatica and the growth and ingestion rates of the heterotrophic dinoflagellate Oxyrrhis marina on B. adriatica BATY06 as a function of prey concentration. The common heterotrophic dinoflagellates Aduncodinium glandula, O. marina, Gyrodinium dominans, Gyrodinium moestrupii, Luciella masanensis, Pfiesteria piscicida, and Oblea rotunda and two naked ciliates Strombidinopsis sp. and Pelagostrobilidium sp. were able to feed on B. adriatica, but the heterotrophic dinoflagellate Polykrikos kofoidii was not. However, B. adriatica supported the positive growth of $O$. marina, but did not support that of G. dominans and O. rotunda. With increasing prey concentrations, the growth and ingestion rates of $O$. marina on B. adriatica increased and became saturated. The maximum growth rate of O. marina on B. adriatica was $0.162 \mathrm{~d}^{-1}$. Furthermore, the maximum ingestion rate of $O$. marina on B. adriatica was $0.2 \mathrm{ng} \mathrm{C}$ predator ${ }^{-1} \mathrm{~d}^{-1}\left(2.0\right.$ cells predator ${ }^{-1}$ $\mathrm{d}^{-1}$ ). In the order Suessiales, the feeding occurrence by common heterotrophic protists on B. adriatica is similar to that on Effrenium voratum and Biecheleria cincta, but different from that on Yihiella yeosuensis. However, the growth and ingestion rates of $O$. marina on B. adriatica are considerably lower than those on E. voratum and B. cincta, but higher than those on Y. yeosuensis. Therefore, B. adriatica may be less preferred prey for O. marina than E. voratum and B. cincta, but more preferred prey than Y. yeosuensis.

Key Words: ciliate; food web; heterotrophic dinoflagellate; predation; protist; Suessiales

\section{INTRODUCTION}

Dinoflagellates are ubiquitous and a major component of marine ecosystems (Lessard 1984, Jeong 1999, Lim et al. 2017b). They have diverse trophic modes, such as exclusively autotrophic, mixotrophic, and heterotrophic (Stoecker 1999, Jeong et al. 2010). Due to their trophic mode diversity, they can play diverse roles in marine planktonic food webs as primary producers, predators on diverse prey items (including bacteria, microalgae, and metazoans), and prey for heterotrophic protists and metazoans (Coats 1999, Tillmann 2004, Hansen 2011, Johnson 2015, Stoecker et al. 2017). Therefore, dinoflagellates are largely involved in the cycling of materials and
(9) $\$$ This is an Open Access article distributed under the terms of the Creative Commons Attribution Non-Commercial License (http://creativecommons.org/licenses/by-nc/3.0/) which permits unrestricted non-commercial use, distribution, and reproduction in any medium, provided the original work is properly cited.
Received March 31, 2019, Accepted May 29, 2019

* Corresponding Author

E-mail: hjjeong@snu.ac.kr

Tel: +82-2-880-6746, Fax: +82-2-874-9695 
energy flow in marine ecosystems (Eppley et al. 1973, Carlsson et al. 1999, Calbet and Landry 2004). Many dinoflagellates species are known to form red tides or harmful algal blooms (HABs), which often cause the large-scale mortality of marine organisms and subsequently great economic loss in diverse industries (Adolf et al. 2015, Menden-Deuer and Montalbano 2015). Thus, to preserve marine organisms and also reduce the economic losses due to red tides or HABs caused by a dinoflagellate, the population dynamics of the dinoflagellate should be well understood. In population dynamics models, the growth and mortality rates of the dinoflagellate are two critical parameters (Jeong et al. 2015). Thus, to understand the roles of a dinoflagellate in marine ecosystems, interactions between the dinoflagellate species and other related organisms (as a potential prey or predator) should be well documented.

Species in the dinoflagellate order Suessiales are known as dinoflagellates, whose cell surface is covered with many thin plates (Lindberg et al. 2005). There are many species in this order (Algaebase, http://www.algaebase.org). However, compared to species in other orders, such as Peridiniales, Gonyaulacales, and Gymnodiniales, there have been fewer species whose predators and mortality rates are reported (Jeong et al. 1997, 2010, Kang et al. 2018). In the order Suessiales, the predators and mortality rates of Effrenium (Symbiodinium) voratum, Biecheleria cincta, Protodinium simplex, and Yihiella yeosuensis have been reported (Strom and Morello 1998, Montagnes and Lessard 1999, Yoo et al. 2013c, Jeong et al. 2014, 2018a). Biecheleriopsis adriatica was reported as a new genus and species of the order Suessiales in 2009 (Moestrup et al. 2009). This species is characterized from other groups of woloszynskioid dinoflagellates by having a nuclear fibrous connective, and a distinct tongue-like process in the left ventral corner of the asymmetric hyposome (Moestrup et al. 2009, Jang et al. 2015). The vegetative cells of B. adriatica were widely distributed in Korean waters (Kang et al. 2019). To understand its ecological roles in marine food webs, its predators and mortality rates should be explored.

Heterotrophic protists are also a major component of marine ecosystems (Sherr and Sherr 2002, Jeong et al. 2010, Lim et al. 2017b). Their grazing impact on phytoplankton populations are usually greater than that of metazoans because the abundance of heterotrophic protist predators is much greater than that of metazoan predators (Turner and Borkman 2005, Lim et al. 2017b). Heterotrophic dinoflagellates (HTDs) and ciliates are major heterotrophic protist groups (Jeong et al. 1999,
Levinsen and Nielsen 2002). They are often effective predators of phototrophic dinoflagellates and sometimes control prey populations (Jeong et al. 2003, Lim et al. 2017a). Aduncodinium glandula, Gyrodinium dominans, Gyrodinium moestrupii, Luciella masanensis, Oblea rotunda, Oxyrrhis marina, Polykrikos kofoidii, and Pfiesteria piscicida are common HTDs and Pelagostrobilidium sp. and Strombidinopsis sp. are also common naked ciliates in many marine environments (Strom and Buskey 1993, Claessens et al. 2008, Taylor et al. 2008, Watts et al. 2010, Calbet et al. 2013, Tillmann and Hoppenrath 2013, Yoo et al. 2013b). There are usually large variations in feeding occurrence and growth and ingestion rates of heterotrophic protist predator species when diverse prey species are provided (Hansen 1992, Menden-Deuer et al. 2005, Jeong et al. 2018a, 2018b, Kang et al. 2018). Thus, it is worthwhile to explore the interactions between $B$. adriatica and these potential heterotrophic protist predators.

In the present study, we investigated the types of predators that are able to feed on a Korean strain of B. adriatica. Furthermore, the growth and ingestion rates of $O$. marina on B. adriatica were measured as a function of prey concentration. The growth and ingestion rates were compared to the rates of the same predator on different species in the order Suessiales. The results of this study provide a basis for understanding the interactions between B. adriatica and common heterotrophic protists, and their ecological roles in the marine planktonic community.

\section{MATERIALS AND METHODS}

\section{Preparation of experimental organisms}

Cells of B. adriatica were isolated from plankton samples that were collected from surface waters off the coast of Tongyoung, Korea using plankton samplers in August 2006, when the water temperature and salinity were $28.0^{\circ} \mathrm{C}$ and 31.0 , respectively (Table 1 ). The collected samples were screened softly by using a $154-\mu \mathrm{m}$ Nitex mesh. The clonal culture of B. adriatica BATY06 was established using two consecutive single-cell isolations (Jang et al. 2015). When the B. adriatica concentration had increased sufficiently, the volume of the bottles increased to 32, 270, and 500-mL PC bottles containing fresh $\mathrm{f} / 2$ medium. The bottles were placed on a shelf at $20^{\circ} \mathrm{C}$, illuminated with an irradiance of $20 \mu \mathrm{mol}$ photons $\mathrm{m}^{-2} \mathrm{~s}^{-1}$ provided by cool white fluorescent lights, under a $14: 10 \mathrm{~h}$ light : dark cycle. Only cultures in the exponen- 
tial growth phase were used.

The HTDs A. glandula, G. dominans, G. moestrupii, L. masanensis, O. rotunda, O. marina, and P. kofoidii, isolated from plankton samples collected from the coastal waters off Masan, Shiwha, Saemankeum, Jinhae, and Jangheung in 2007-2016 were used in this study (Table 1). A clonal culture of each HTD species was established using two consecutive single-cell isolations, except for that of P. piscicida, which was obtained from the National Center for Marine Algae and Microbiota (NCMA), USA. The naked ciliates Pelagostrobilidium sp. and Strombidinopsis sp. were isolated from plankton samples, collected using 20- and 10- $\mu \mathrm{m}$ mesh nets from the coastal waters off Tongyoung and Yeosu in August 2017 and July 2018, respectively (Table 1). A clonal culture for each of Pelagostrobilidium sp. and Strombidinopsis sp. was also established using two serial single-cell isolations.

The carbon content of B. adriatica BATY06 (0.1 ng C per cell) was estimated from the cell volume, according to the equation suggested by Menden-Deuer and Lessard (2000). Furthermore, the carbon contents of all predator species used in the present study were also estimated from the cell volume as described above. The cell volumes of the HTD predators were estimated using the methods of Jang et al. (2016) for A. glandula; Kim and Jeong (2004) and Yoo et al. (2013b) for G. dominans and G. moestrupii, respectively; Jeong et al. (2007) for L. masanensis and P. piscicida; Ok et al. (2017) for O. rotunda; Jeong et al. (2008b) for O. marina; Jeong et al. (2001b) for P. kofoidii; Kim et al. (2019) for Strombidinopsis sp.; and Jeong et al. (2018b) for Pelagostrobilidium sp. (Table 1).

\section{Interactions between Bicheleriopsis adriatica and heterotrophic protists}

Experiment (Expt) 1 was designed to investigate feeding by each of the HTDs and ciliates on $B$. adriatica BATY06, after mixing $B$. adriatica with potential predator species (Table 2). In this experiment, whether the target heterotrophic protist was able to feed on B. adriatica and / or other interactions were observed.

Dense cultures of B. adriatica (ca. 40,000 cells $\mathrm{mL}^{-1}$ ) and each of the HTDs and ciliates were added to each 42mL PC bottle (Table 2). For each experiment, one experiment (with prey and predator), one prey control (without predator), and one predator control (without prey) bot-

Table 1. Conditions for the isolation and maintenance of the experimental organisms

\begin{tabular}{|c|c|c|c|c|c|c|c|c|c|}
\hline $\begin{array}{c}\text { Organisms } \\
\text { (strain name) }\end{array}$ & Type & FM & $\mathrm{CV}$ & Location & Time & $T$ & $\mathrm{~S}$ & $\begin{array}{l}\text { Prey species for } \\
\text { maintenance }\end{array}$ & $\begin{array}{c}\text { Feeding } \\
\text { of } \mathrm{Ba}\end{array}$ \\
\hline \multicolumn{10}{|l|}{ Predators } \\
\hline $\begin{array}{l}\text { Aduncodinium glandula } \\
\text { (AGMS1303) }\end{array}$ & HTD & $\mathrm{PD}$ & 4.8 & Masan, Korea & Mar 2013 & 8.1 & 30.3 & As & $\mathrm{Y}$ \\
\hline $\begin{array}{l}\text { Gyrodinium dominans } \\
\text { (GDMS0907) }\end{array}$ & HTD & EG & 4.2 & Masan, Korea & Apr 2007 & 15.1 & 33.4 & $A c$ & $\mathrm{Y}$ \\
\hline $\begin{array}{l}\text { Gyrodinium moestrupii } \\
\text { (GMSMK0910) }\end{array}$ & HTD & EG & 3.3 & Saemankeum, Korea & Oct 2009 & 21.2 & 31.0 & $A m$ & $\mathrm{Y}$ \\
\hline $\begin{array}{l}\text { Luciella masanensis } \\
\text { (LMJH1607) }\end{array}$ & HTD & $\mathrm{PD}$ & 1.3 & Jinhae, Korea & Jul 2016 & 22.6 & 30.7 & Api & $\mathrm{Y}$ \\
\hline $\begin{array}{l}\text { Oblea rotunda } \\
\text { (ORJH1504) }\end{array}$ & HTD & $\mathrm{PA}$ & 5.3 & Jinhae, Korea & Apr 2015 & 12.6 & 31.2 & $A c$ & $\mathrm{Y}$ \\
\hline $\begin{array}{l}\text { Oxyrrhis marina } \\
\text { (OMSH0811) }\end{array}$ & HTD & EG & 2.0 & Shiwha, Korea & Nov 2008 & 16.8 & 27.0 & $A c$ & $\mathrm{Y}$ \\
\hline $\begin{array}{l}\text { Polykrikos kofoidii } \\
\text { (PKJH1607) }\end{array}$ & HTD & EG & 43.1 & Jangheung, Korea & Jul 2016 & 23.6 & 26.4 & $S a$ & $\mathrm{~N}$ \\
\hline $\begin{array}{l}\text { Pfiesteria piscicida } \\
\text { (CCMP2091) }\end{array}$ & HTD & $\mathrm{PD}$ & 1.3 & Neuse River, USA & Jan 1998 & - & - & $A c$ & $\mathrm{Y}$ \\
\hline $\begin{array}{l}\text { Pelagostrobilidium sp. } \\
\text { (PSTY1708) }\end{array}$ & NC & $\mathrm{FF}$ & 25.1 & Tongyoung, Korea & Aug 2017 & 27.2 & 31.5 & $P c$ & $\mathrm{Y}$ \\
\hline $\begin{array}{l}\text { Strombidinopsis sp. } \\
\text { (SSYS1807) }\end{array}$ & NC & $\mathrm{FF}$ & 383.0 & Yeosu, Korea & Jul 2018 & 27.5 & 32.4 & $K t$ & $\mathrm{Y}$ \\
\hline \multicolumn{10}{|l|}{ Prey } \\
\hline $\begin{array}{l}\text { Biecheleriopsis adriatica } \\
\text { (BATY06) }\end{array}$ & ATD & - & 0.5 & Tongyoung, Korea & Aug 2006 & 28.0 & 31.0 & - & - \\
\hline
\end{tabular}

$\mathrm{FM}$, feeding mechanism; CV, cell volume $\left(\times 10^{3} \mu \mathrm{m}^{3}\right) ; \mathrm{T}$, temperature $\left({ }^{\circ} \mathrm{C}\right) ; \mathrm{S}$, salinity; Ba, Biecheleriopsis adriatica; HTD, heterotrophic dinoflagellate; $\mathrm{NC}$, naked ciliate; ATD, autotrophic dinoflagellate; PD, peduncle feeder; EG, engulfment feeder; PA, pallium feeder; FF, filter feeder; As, Akashiwo sanguinea; Ac, Amphidinium carterae; Am, Alexandrium minutum; Api, Apistonema sp.; Sa, Scrippsiella acuminata; Pc, Prorocentrum cordatum; Kt, Kryptoperidinium triquetrum; $\mathrm{Y}$, feeding; $\mathrm{N}$, no feeding; -, not available. 
tles were set up. The bottles for the A. glandula predator were placed on a shelf, but the bottles for the rest of the predators were placed on a rotating wheel at $0.00017 \mathrm{~g}$ ( $0.9 \mathrm{rpm})$. All bottles were incubated at $20^{\circ} \mathrm{C}$, under an illumination of $20 \mu \mathrm{mol}$ photons $\mathrm{m}^{-2} \mathrm{~s}^{-1}$ and a $14: 10 \mathrm{~h}$ light : dark cycle.

After 2, 24, and $48 \mathrm{~h}$ of incubation, $3 \mathrm{~mL}$ aliquots were taken from each bottle and transferred into the wells of 6 -well plate chambers. More than 30 cells of each predator in one plate chamber were tracked for 2 min under a dissecting microscope at 20-63× magnification to determine whether the predator was able to feed on B. adriatica. The cells of predators having ingested cells of $B$. adriatica in their body were photographed on slides with cover-glasses at a $200-400 \times$ magnification using a digital camera (Zeiss-AxioCam MRc5; Carl Zeiss Ltd., Göttingen, Germany) attached to an inverted light microscope (Zeiss-Axiovert 200 M; Carl Zeiss Ltd.). The feeding process of each of these heterotrophic protists on B. adriatica was recorded using a video analyzing system (Sony DXC-C33; Sony Co., Tokyo, Japan) and captured using the digital camera.

\section{Growth and ingestion rates of Oxyrrhis marina feeding on Biecheleriopsis adriatica as a function of prey concentration}

Expt 2 was designed to measure the growth and ingestion rates of O. marina feeding on B. adriatica BATY06 as a function of prey concentration (Table 2). In preliminary tests, B. adriatica BATY06 supported the positive growth of $O$. marina, but did not support the positive growth of $G$. dominans, $O$. rotunda, and Strombidinopsis sp. Whether B. adriatica supports the positive growth of A. glandula,
P. piscicida, and L. masanensis was not tested because these dinoflagellates were not distinguishable from $B$. adriatica when fixed with Lugol's solution and formalin.

Dense cultures of $O$. marina grown with Amphidinium carterae as prey were transferred into 250 -mL PC bottles when cells of A. carterae were not detectable for $24 \mathrm{~h}$. The bottles were filled to capacity with freshly filtered seawater, capped, placed on a plankton wheel rotating at $0.00017 \mathrm{~g}(0.9 \mathrm{rpm})$, and incubated at $20^{\circ} \mathrm{C}$ under an illumination of $20 \mu \mathrm{mol}$ photons $\mathrm{m}^{-2} \mathrm{~s}^{-1}$ and a $14: 10 \mathrm{~h}$ light : dark cycle. This was done to minimize the possible residual growth resulting from the ingestion of prey during the batch culture. After one day, the cells in three $1 \mathrm{~mL}$ aliquots from each bottle were counted using a compound microscope to determine the concentration of predator cells, and the cultures were used in further experiments.

The initial concentrations of O. marina and B. adriatica were established in eight different combinations. Triplicate 42-mL PC experimental bottles (mixtures of predator and prey) and triplicate control bottles (prey only) were set up at each predator-prey combination. In addition, triplicate control bottles (predator only) were established at a single predator concentration. Predetermined volumes of O. marina and B. adriatica were added into each bottle using an autopipette. To obtain similar water conditions, the water of the predator culture was filtered through a $0.7-\mu \mathrm{m} \mathrm{GF} / \mathrm{F}$ filter, and then added to the prey control bottles in the same amount as the volume of the predator culture added into the experiment bottles for each predator-prey combination. Similarly, the water of the prey culture was filtered through a 0.7$\mu \mathrm{m}$ GF/F filter and then added to the predator control bottles in the same amount as the volume of the prey culture added into the experimental bottles. To all the

Table 2. Experimental design

\begin{tabular}{|c|c|c|c|c|}
\hline \multirow{2}{*}{$\begin{array}{c}\text { Expt. } \\
\text { No. }\end{array}$} & \multicolumn{2}{|c|}{ Prey } & \multicolumn{2}{|c|}{ Predator } \\
\hline & Species & Density & Species & Density \\
\hline & Biecheleriopsis adriatica & 20,000 & Aduncodinium glandula & 1,000 \\
\hline & & & Gyrodinium dominans & 1,000 \\
\hline & & & Gyrodinium moestrupii & 500 \\
\hline & & & Luciella masanensis & 4,000 \\
\hline & & & Oblea rotunda & 800 \\
\hline & & & Oxyrrhis marina & 4,000 \\
\hline & & & Polykrikos kofoidii & 100 \\
\hline & & & Pfiesteria piscicida & 2,000 \\
\hline & & & Pelagostrobilidium sp. & 50 \\
\hline & & & Strombidinopsis sp. & 20 \\
\hline
\end{tabular}

The numbers in the prey and predator columns are the initial densities (cells $\mathrm{mL}^{-1}$ ) of the prey and predator. The predator density in the control bottle is in parentheses. 

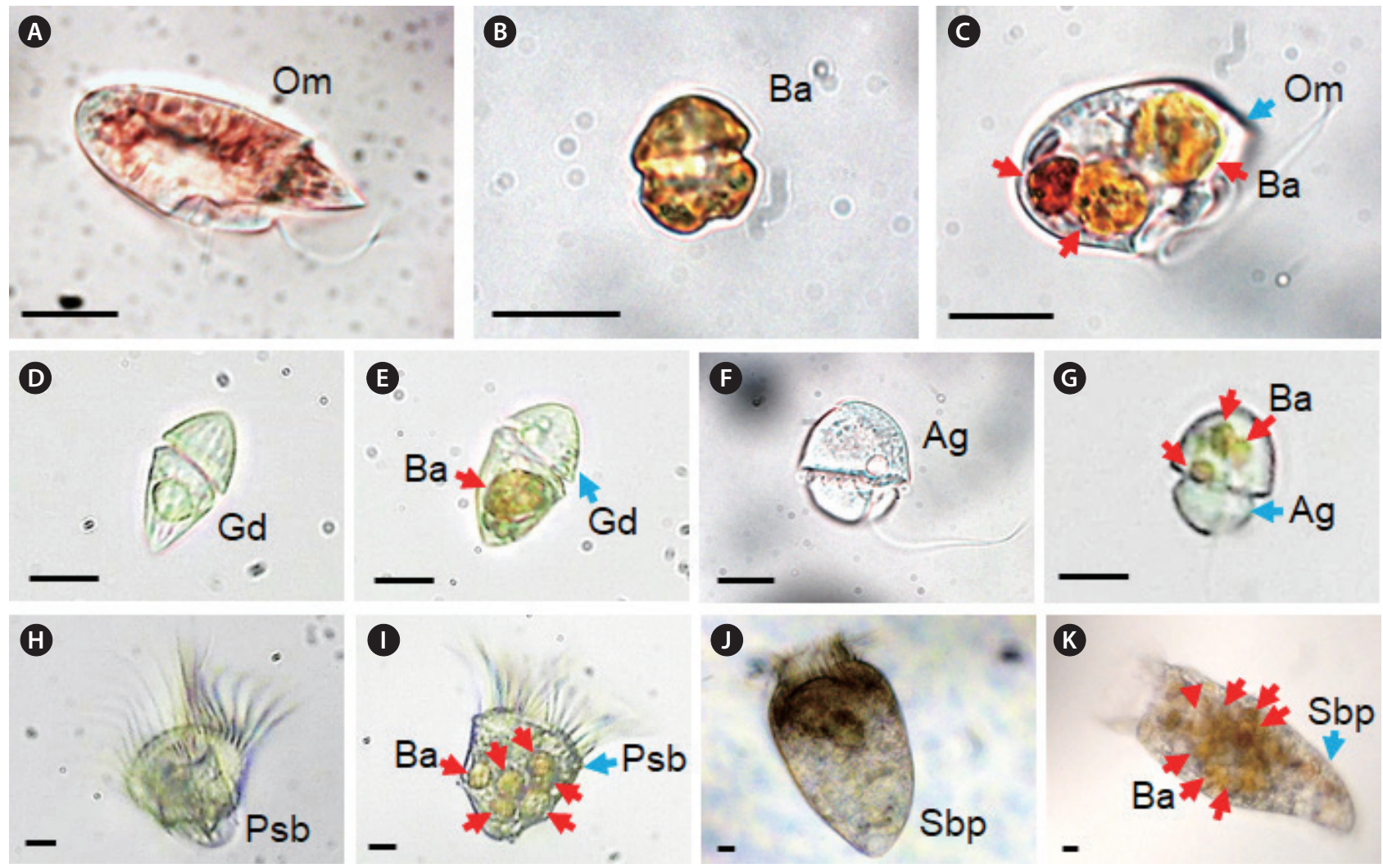

Fig. 1. Feeding by the heterotrophic dinoflagellates and ciliates on Biecheleriopsis adriatica (Ba). (A) Unfed Oxyrrhis marina (Om). (B) Intact Ba cell. (C) Om with three ingested Ba cells. (D) Unfed Gyrodinium dominans (Gd). (E) Gd with an ingested Ba cell. (F) Unfed Aduncodinium glandula (Ag). (G) Ag with ingested Ba cells. (H) Unfed Pelagostrobilidium sp. (Psb). (I) Psb with several ingested Ba cells. (J) Unfed Strombidinopsis sp. (Sbp). (K) Sbp with several ingested Ba cells. Scale bars represent: A-K, $10 \mu \mathrm{m}$.

bottles, $5 \mathrm{~mL}$ of $\mathrm{f} / 2$ medium was added to provide sufficient nutrients to $B$. adriatica grown autotrophically, and then filled to capacity with freshly filtered seawater and capped. To determine the actual initial predator and prey densities at the beginning of the experiment, a $5 \mathrm{~mL}$ aliquot was sampled from each bottle, fixed with $5 \%$ Lugol's solution, and enumerated in three 1-mL Sedgewick Rafter chambers (SRCs). The bottles were then refilled to capacity with freshly filtered seawater, capped, and placed on rotating wheels at $0.00017 \mathrm{~g}$ under the conditions described above. Dilution of the cultures from the refilling of bottles was considered when calculating the growth and ingestion rates. A $10 \mathrm{~mL}$ aliquot was taken from each bottle at $48 \mathrm{~h}$ and fixed with 5\% Lugol's solution, and the abundances of predators and prey were then determined by counting all or $>200$ cells in three 1 -mL SRCs.

The specific growth rate of a heterotrophic protist predator, $\mu\left(\mathrm{d}^{-1}\right)$ was calculated according to following formula:

$$
\mu\left(\mathrm{d}^{-1}\right)=\left[\operatorname{Ln}\left(\mathrm{P}_{\mathrm{t}} / \mathrm{P}_{0}\right)\right] / \mathrm{t}
$$

, where $\mathrm{P}_{0}$ and $\mathrm{P}_{\mathrm{t}}=$ the concentrations of the predator at 0 and $2 \mathrm{~d}$.

Data for O. marina growth rates were fitted to a modified Michaelis-Menten equation:

$$
\mu\left(d^{-1}\right)=\mu_{\max }\left(x-x^{\prime}\right) /\left[K_{G R}+\left(x-x^{\prime}\right)\right]
$$

, where $\mu_{\max }=$ the maximum growth rate $\left(\mathrm{d}^{-1}\right) ; \mathrm{x}=$ prey concentration (cells $\mathrm{mL}^{-1}$ or $\mathrm{ng} \mathrm{C} \mathrm{mL} \mathrm{m}^{-1}$ ), $\mathrm{x}^{\prime}=$ threshold of prey concentration (where the prey concentration $\mu=$ 0 ), and $\mathrm{K}_{\mathrm{GR}}=$ the prey concentration sustaining $1 / 2 \mu_{\max }$. Data were iteratively fitted to the model using DeltaGraph (Red Rock Software Inc., Salt Lake, UT, USA).

The ingestion rate and mean prey concentration were calculated using the equations of Frost (1972) and Heinbokel (1978), respectively. The incubation time for calculating ingestion was the same as that for estimat- 


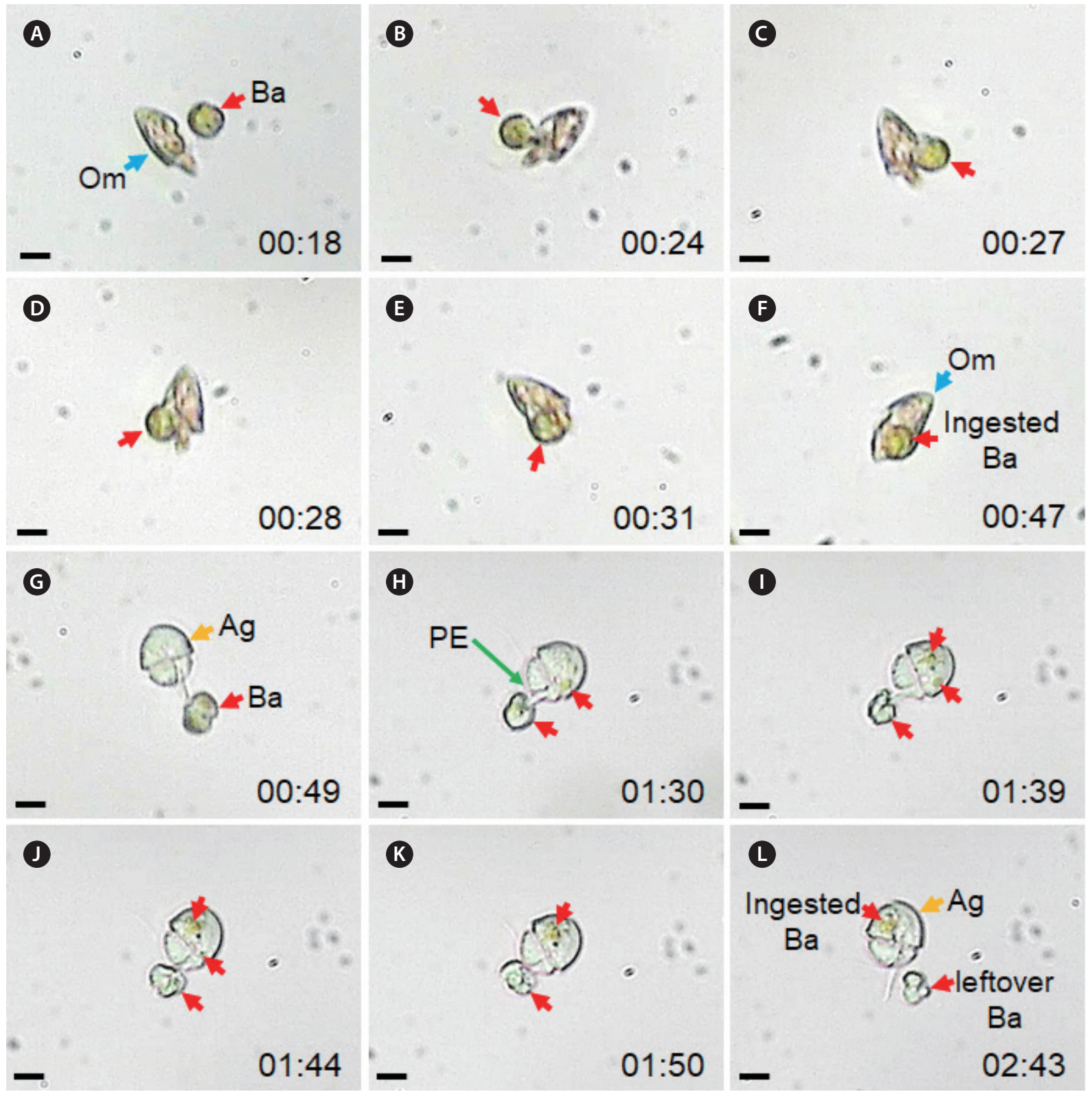

Fig. 2. Feeding process by Oxyrrhis marina (Om) and Aduncodinium glandula (Ag) on Biecheleriopsis adriatica (Ba). (A-F) Om engulfed a whole Ba cell. (G-L) Ag fed on a Ba cell using a peduncle (PE). The numbers were min:sec. Scale bars represent: A-L, $10 \mu \mathrm{m}$.

ing growth rate. Data for O. marina ingestion rates (IR, cells predator ${ }^{-1} \mathrm{~d}^{-1}$ or ng C predator ${ }^{-1} \mathrm{~d}^{-1}$ ) were fitted into a modified Michaelis-Menten equation:

$$
\mathrm{IR}=\mathrm{I}_{\max }(\mathrm{x}) /\left[\mathrm{K}_{\mathrm{IR}}+(\mathrm{x})\right]
$$

, where $\mathrm{I}_{\max }=$ the maximum ingestion rate (cells predator $^{-1} \mathrm{~d}^{-1}$ or ng $\mathrm{C}$ predator $\left.{ }^{-1} \mathrm{~d}^{-1}\right) ; \mathrm{x}=$ prey concentration (cells $\mathrm{mL}^{-1}$ or $\mathrm{ng} \mathrm{C} \mathrm{mL}^{-1}$ ), and $\mathrm{K}_{\mathrm{IR}}=$ the prey concentration sustaining $1 / 2 \mathrm{I}_{\max }$.

\section{RESULTS \\ Interactions between Biecheleriopsis adriatica and heterotrophic protists}

The HTDs A. glandula, O. marina, G. dominans, G. moestrupii, L. masanensis, P. piscicida, and O. rotunda and the ciliates Strombidinopsis sp. and Pelagostrobilidium sp. were able to feed on B. adriatica BATY06, but the HTD P. kofoidii was not (Table 1, Fig. 1). Cells of $O$. 


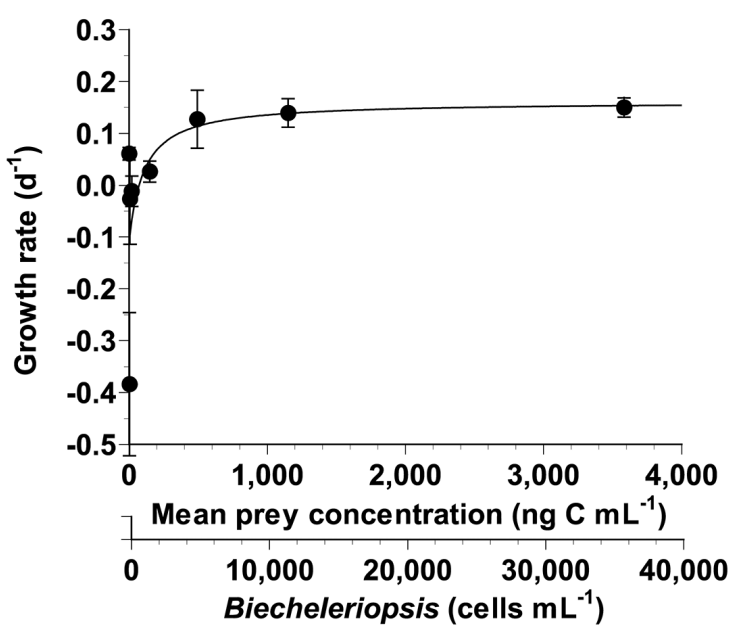

Fig. 3. Specific growth rates of the heterotrophic dinoflagellate $O x$ yrrhis marina on Biecheleriopsis adriatica as a function of mean prey concentration $(\mathrm{x})$. Symbols represent treatment means \pm standard error. The curves are fitted by a Michaelis-Menten equation (Eq. 2) using all treatments in the experiment. Growth rate $\left(d^{-1}\right)=0.162\{[x-$ $72.9] /[182+(x-72.9)]\}, r^{2}=0.335$.

marina, G. dominans, G. moestrupii, Strombidinopsis sp., and Pelagostrobilidium sp. engulfed a whole B. adriatica cell. Furthermore, L. masanensis and P. piscicida fed on a $B$. adriatica cell using a peduncle. Moreover, $O$. rotunda fed on a $B$. adriatica cell using a pallium after anchoring the prey cell using a tow filament. However, $P$. kofoidii did not deploy the nematocyst-taeniocyst complex to $B$. adriatica cells.

O. marina engulfed whole B. adriatica cells (Fig. 2A-F). The time for a $B$. adriatica cell to be completely engulfed by $O$. marina was ca. $40-50 \mathrm{~s}$. Meanwhile, A. glandula deployed the peduncle to the body of $B$. adriatica and then sucked the body materials of B. adriatica (Fig. 2G-L). The A. glandula sometimes left some residual materials of the B. adriatica body. The time for a B. adriatica cell to be ingested by A. glandula was ca. 120-180 s (Fig. 2G-L).

\section{Growth and ingestion rates of Oxyrrhis marina feeding on Biecheleriopsis adriatica as a function of prey concentration}

With increasing mean prey concentrations, the specific growth rate of O. marina feeding on B. adriatica BATY06 increased at $B$. adriatica concentrations $<493 \mathrm{ng} \mathrm{C} \mathrm{mL}^{-1}$ (4,930 cells $\left.\mathrm{mL}^{-1}\right)$, but became saturated at higher mean prey concentrations (Fig. 3). When the data were fitted to Eq. (2), the calculated maximum growth rate $\left(\mu_{\max }\right)$ of $O$. marina on B. adriatica was $0.162 \mathrm{~d}^{-1}$.

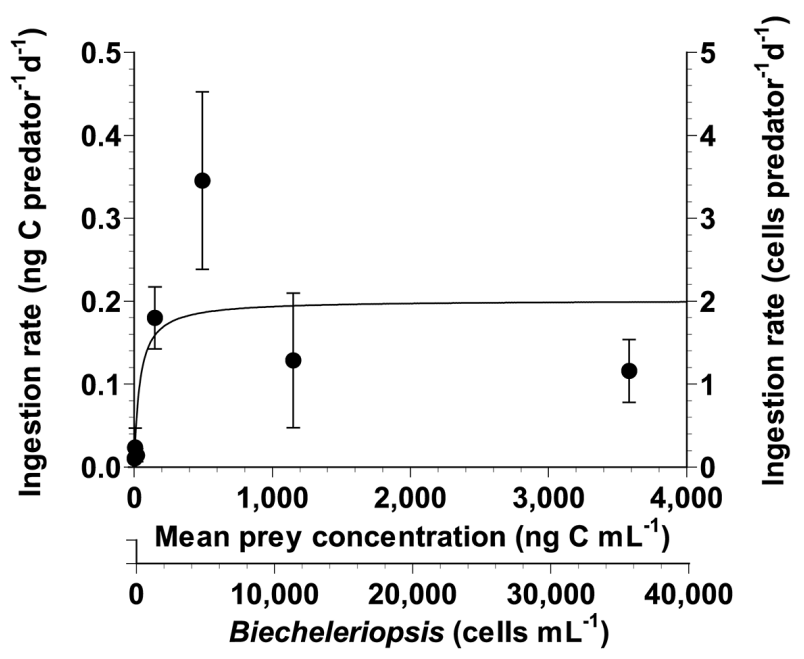

Fig. 4. Ingestion rates of the heterotrophic dinoflagellate Oxyrrhis marina on Biecheleriopsis adriatica as a function of mean prey concentration (x). Symbols represent treatment means \pm standard error. The curves are fitted by a Michaelis-Menten equation (Eq. 3) using all treatments in the experiment. Ingestion rate $\left(\mathrm{ngC}\right.$ predator $\left.{ }^{-1} \mathrm{~d}^{-1}\right)=$ $0.2[x /(39.8+x)], r^{2}=0.366$.

With increasing mean prey concentrations, the ingestion rate of $O$. marina feeding on $B$. adriatica increased at $B$. adriatica concentrations $<493 \mathrm{ng} \mathrm{C} \mathrm{mL}^{-1}(4,930$ cells $\left.\mathrm{mL}^{-1}\right)$, but became almost saturated at higher mean prey concentrations (Fig. 4). The highest ingestion rate was 0.35 ng C predator ${ }^{-1} \mathrm{~d}^{-1}\left(3.5\right.$ cells predator $\left.{ }^{-1} \mathrm{~d}^{-1}\right)$. However, when the data were fitted to Eq. (3), the calculated maximum ingestion rate $\left(\mathrm{I}_{\max }\right)$ of O. marina on B. adriatica was $0.2 \mathrm{ng} C$ predator ${ }^{-1} \mathrm{~d}^{-1}\left(2.0\right.$ cells predator $\left.{ }^{-1} \mathrm{~d}^{-1}\right)$.

\section{DISCUSSION}

Prior to the present study, among the species belonging to the order Suessiales, only a few have been tested regarding whether common heterotrophic protist predators are able to feed on the prey species or not. The results of the present study clearly showed that among the common heterotrophic protist predators tested, all of the predators except for $P$. kofoidii were able to feed on B. adriatica BATY06. The minimum prey size that $P$. kofoidii is able to feed on is known to be approximately 10 $\mu \mathrm{m}$ (Jeong et al. 2001b). The average size of B. adriatica tested in this study was $10.1 \mu \mathrm{m}$. Thus, the small size of $B$. adriatica may be partially responsible for it not been fed upon by P. kofoidii, which deploys the nematocyst-taeniocyst complex to anchor prey cells. The types of common heterotrophic protist predators that are able to feed 
on $B$. adriatica were identical or very similar to $E$. voratum and B. cincta, but largely different from Y. yeosuensis, which only O. marina, A. glandula, and Strombidinopsis sp. were able to feed on (Table 3 ). Thus, $B$. adriatica is vulnerable to common heterotrophic protist predators as much as E. voratum and B. cincta; however, it is more vulnerable than $Y$. yeosuensis. Furthermore, the $\mu_{\max }$ and $\mathrm{I}_{\max }$ of $O$. marina on B. adriatica was lower than those of E. voratum and B. cincta, but greater than those of Y. yeosuensis (Table 4). Thus, it is expected that in marine environments, O. marina is less abundant when $B$. adriatica is abundant than when E. voratum or B. cincta is abundant, but more abundant than when $Y$. yeosuensis prey is abundant. Meanwhile, either the $\mu_{\max }$ or $\mathrm{I}_{\max }$ of $O$. marina feeding on B. adriatica, B. cincta, E. voratum, and Y. yeosuensis was not significantly related to the size of the prey species (Fig. 5A \& B). Thus, factors other than prey size may affect the $\mu_{\max }$ or $\mathrm{I}_{\max }$ of $O$. marina. The maximum swimming speeds of B. adriatica and $Y$. yeosuensis were much greater than those of B. cincta and E. voratum (Table 4). Furthermore, B. adriatica and Y. yeosuensis jump backward when a predator attacks, whereas B. cincta and E. voratum do not jump (Kang et al. 2011, Yoo et al. 2013c, Jeong et al. 2014, 2018a, Jang et al. 2015, 2017, personal observation). Thus, the much higher maximum swimming speeds and jumping behaviors of B. adriatica and $Y$. yeosuensis may be partially responsible for the lower $\mu_{\max }$ or $\mathrm{I}_{\max }$ of $O$. marina on these prey species compared to those on B. cincta and E. voratum. The $\mu_{\max }$ of $O$. marina feeding on B. adriatica, B. cincta, E. voratum, and $Y$. yeosuensis was also not significantly related to $\mathrm{I}_{\max }$ (Fig. $5 \mathrm{C}$ ). Thus, the gross growth efficiencies (GGEs) of $O$. $m a$ rina on these four dinoflagellate prey species are different (Table 4). The GGE of O. marina on B. adriatica (18\%) is lower than that on $B$. cincta (27\%), but higher than that on E. voratum (10\%) or Y. yeosuensis ( $0 \%)$. Thus, the GGEs of $O$. marina on these suessioid dinoflagellate prey species are wide.

When the $\mu_{\max }$ and $I_{\max }$ of O. marina on B. adriatica
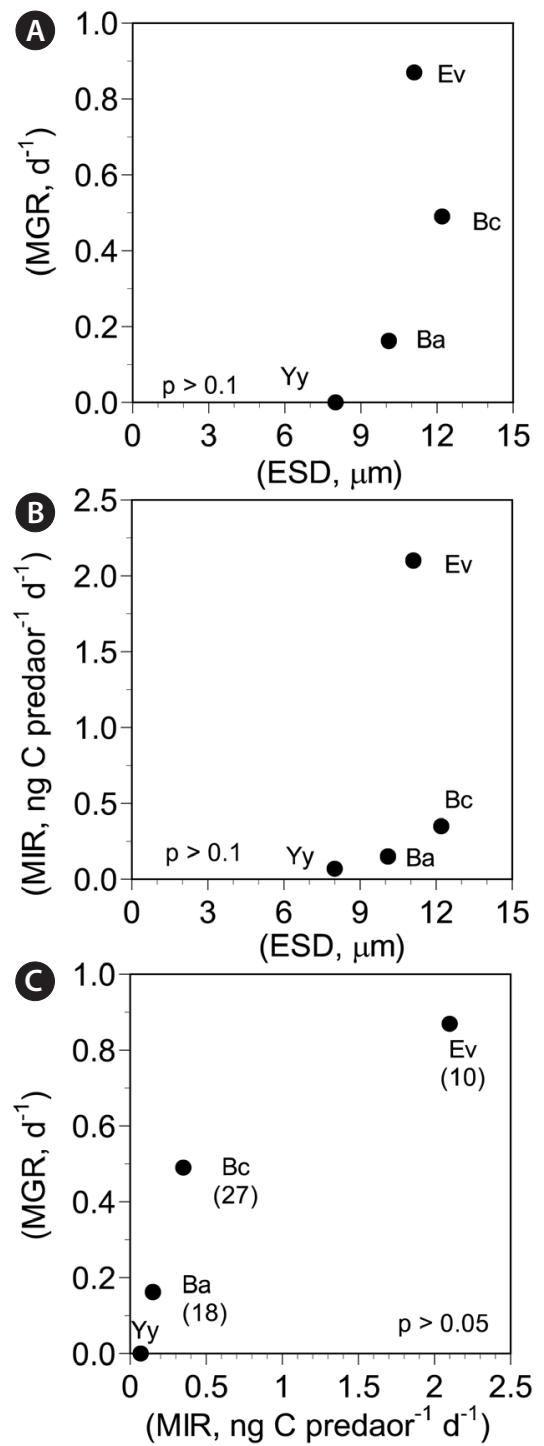

Fig. 5. Maximum growth (MGR) and ingestion (MIR) rates of Oxyrrhis marina predators on the suessioid dinoflagellate prey species. (A) MGR as a function of equivalent spherical diameter (ESD, $\mu \mathrm{m}$ ). (B) MIR as a function of ESD. (C) MGR as a function of MIR. The numbers in parentheses are gross growth efficiencies. Ba, Biecheleriopsis adriatica; $\mathrm{Bc}$, Biecheleria cincta; Ev, Effrenium voratum; Yy, Yihiella yeosuensis.

Table 3. Feeding occurrence of heterotrophic protists on four species in the order Suessiales

\begin{tabular}{lccccccccccc}
\hline \multicolumn{1}{c}{ Prey / Predators } & ESD & Om & Gd & Gm & Pk & Pp & Lm & Ag & Or & NC & Reference \\
\hline Yihiella yeosuensis & 8.0 & $\circ$ & $\times$ & $\times$ & $\times$ & $\times$ & $\times$ & $\circ$ & $\times$ & $\circ$ & Jeong et al. (2018a) \\
Biecheleriopsis adriatica & 10.1 & $\circ$ & $\circ$ & $\circ$ & $\times$ & $\circ$ & $\circ$ & $\circ$ & $\circ$ & $\circ$ & This study \\
Effrenium voratum & 11.1 & $\circ$ & $\circ$ & $\circ$ & $\circ$ & $\circ$ & $\circ$ & $\circ$ & $\circ$ & $\circ$ & Jeong et al. (2014), this study \\
Biecheleria cincta & 12.2 & $\circ$ & $\circ$ & $\circ$ & $\circ$ & $\circ$ & $\circ$ & $\circ$ & $\circ$ & $\circ$ & Yoo et al. (2013c), this study \\
\hline
\end{tabular}

ESD, equivalent spherical diameter ( $\mu \mathrm{m})$; Om, Oxyrrhis marina; Gd, Gyrodinium dominans; Gm, Gyrodinium moestrupii; Pk, Polykrikos kofoidii; Pp, Pfiesteria piscicida; Lm, Luciella masanensis; Ag, Aduncodinium glandula; Or, Oblea rotunda; NC, naked ciliates. 
BATY06 were compared with those on the dinoflagellate species belonging to the other orders, the $\mu_{\max }$ of $O$. marina on B. adriatica were higher than that on the HTD L. masanensis and the mixotrophic dinoflagellates Paragymnodinium shiwhaense and Takayama helix, but lower than that on many species belonging to other orders, such as Amphidiniales, Gymnodiniales, Thoracosphaerales, Chlamydomonadales, Isochrysidales, Chattonellales, and Eutreptiales (Table 5). Furthermore, the $I_{\max }$ of $O$. marina on B. adriatica was higher than that on L. masanensis, Stoeckeria algicida, P. shiwhaense, and T. helix, but lower than that on many species belonging to other orders Amphidiniales, Gymnodiniales, Thoracosphaerales, Chlamydomonadales, Isochrysidales, Chattonellales, and Eutreptiales (Table 5). Therefore, B. adriatica may not be preferred prey for $O$. marina.

Vegetative cells of B. adriatica was present in the waters of 20 stations when surface water samples were collected from 28 stations along the Korean Peninsula and Jeju Island from April 2015 to October 2018 (Kang et al. 2019). However, the maximum abundance of $B$. adriatica in that study was 41.7 cells $\mathrm{mL}^{-1}$ (4.2 $\mathrm{ng} \mathrm{C} \mathrm{mL}^{-1}$ ), which is lower than the threshold prey concentration for the growth of O. marina feeding on B. adriatica $\left(729\right.$ cells $\mathrm{mL}^{-1}, 72.9 \mathrm{ng}$ $\mathrm{C} \mathrm{mL}{ }^{-1}$ ) obtained in the present study. Furthermore, the highest reported abundance of $B$. adriatica in the world's

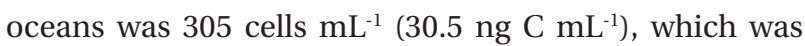
obtained from Bolinao in the Philippines (Benico et al.

Table 4. Maximum growth rate $\left(\mu_{\max } \mathrm{d}^{-1}\right)$, maximum ingestion rate $\left(I_{\max }, \mathrm{ng} C\right.$ predator $\left.{ }^{-1} \mathrm{~d}^{-1}\right)$, and gross growth efficiencies (GGE, \%) of Oxyrrhis marina on the species in the order Suessiales

\begin{tabular}{lrrrccl}
\hline \multicolumn{1}{c}{ Prey } & ESD & MSS & $\boldsymbol{\mu}_{\max }$ & $\mathbf{I}_{\max }$ & GGE & \multicolumn{1}{c}{ Reference } \\
\hline Yihiella yeosuensis & 8.0 & 1,572 & 0 & 0.07 & 0 & Jang et al. (2017), Jeong et al. (2018a) \\
Biecheleriopsis adriatica & 10.1 & 1,119 & 0.162 & 0.15 & 18 & Jang et al. (2015), this study \\
Effrenium voratum & 11.1 & 340 & 0.869 & 2.10 & 10 & Jeong et al. (2014), this study \\
Biecheleria cincta & 12.2 & 265 & 0.490 & 0.35 & 27 & Kang et al. (2011), Yoo et al. (2013c) \\
\hline
\end{tabular}

ESD, equivalent spherical diameter $(\mu \mathrm{m})$; MSS, maximum swimming speed $\left(\mu \mathrm{m} \mathrm{s}^{-1}\right)$.

Table 5. Comparison of maximum growth rate $\left(\mu_{\max }, \mathrm{d}^{-1}\right)$ and maximum ingestion rate $\left(I_{\max }, \mathrm{ng} \mathrm{C}\right.$ predator $\left.\mathrm{d}^{-1}\right)$ of $O x y r r h i s$ marina on prey species in diverse orders

\begin{tabular}{|c|c|c|c|c|}
\hline Prey order / Species & ESD & $\mu_{\max }$ & $\mathbf{I}_{\max }$ & Reference \\
\hline \multicolumn{5}{|l|}{ Amphidiniales } \\
\hline Amphidinium carterae & 9.7 & 1.17 & 2.8 & Jeong et al. (2001a) \\
\hline \multicolumn{5}{|l|}{ Gymnodiniales } \\
\hline Karlodinium veneficum_NTX & 9.1 & 0.85 & 6.36 & Adolf et al. (2007) \\
\hline Karlodinium veneficum_TX & 10.5 & 0.25 & 2.36 & Adolf et al. (2007) \\
\hline Gymnodinium smaydae & 10.5 & 0.41 & 0.27 & Jeong et al. (2018b) \\
\hline Paragymnodinium shiwhaense & 13.0 & -0.18 & 0.01 & Jeong et al. (2017a) \\
\hline Gymnodinium aureolum & 19.5 & 0.71 & 0.51 & Yoo et al. (2010) \\
\hline Takayama helix & 27.4 & 0 & 0 & Ok et al. (2017) \\
\hline \multicolumn{5}{|l|}{ Thoracosphaerales } \\
\hline Luciella masanensis & 13.5 & 0.04 & 0.07 & Jeong et al. (2007) \\
\hline Pfiesteria piscicida & 13.5 & 0.66 & 0.33 & Jeong et al. (2007) \\
\hline Stoeckeria algicida & 13.9 & 0.22 & 0.14 & Jeong et al. (2007) \\
\hline \multicolumn{5}{|l|}{ Chlamydomonadales } \\
\hline Brachiomonas submarina & 10.5 & 0.73 & 1.29 & Fuller (1990) \\
\hline \multicolumn{5}{|l|}{ Isochrysidales } \\
\hline Emiliania huxleyi & 4.1 & 0.37 & 2.65 & Strom et al. (2003) \\
\hline Isochrysis galbana & 5.0 & 0.94 & 1.43 & Kimmance et al. (2006) \\
\hline \multicolumn{5}{|l|}{ Chattonellales } \\
\hline Heterosigma akashiwo & 11.5 & 1.43 & 1.25 & Jeong et al. (2003) \\
\hline Fibrocapsa japonica & 20.4 & 0.72 & 1.18 & Tillmann and Reckermann (2002) \\
\hline \multicolumn{5}{|l|}{ Eutreptiales } \\
\hline Eutreptiella gymnastica & 12.6 & 0.81 & 2.7 & Jeong et al. (2011) \\
\hline
\end{tabular}

The rates for the species in the order Suessiales are shown in Table 4.

ESD, equivalent spherical diameter $(\mu \mathrm{m})$. 


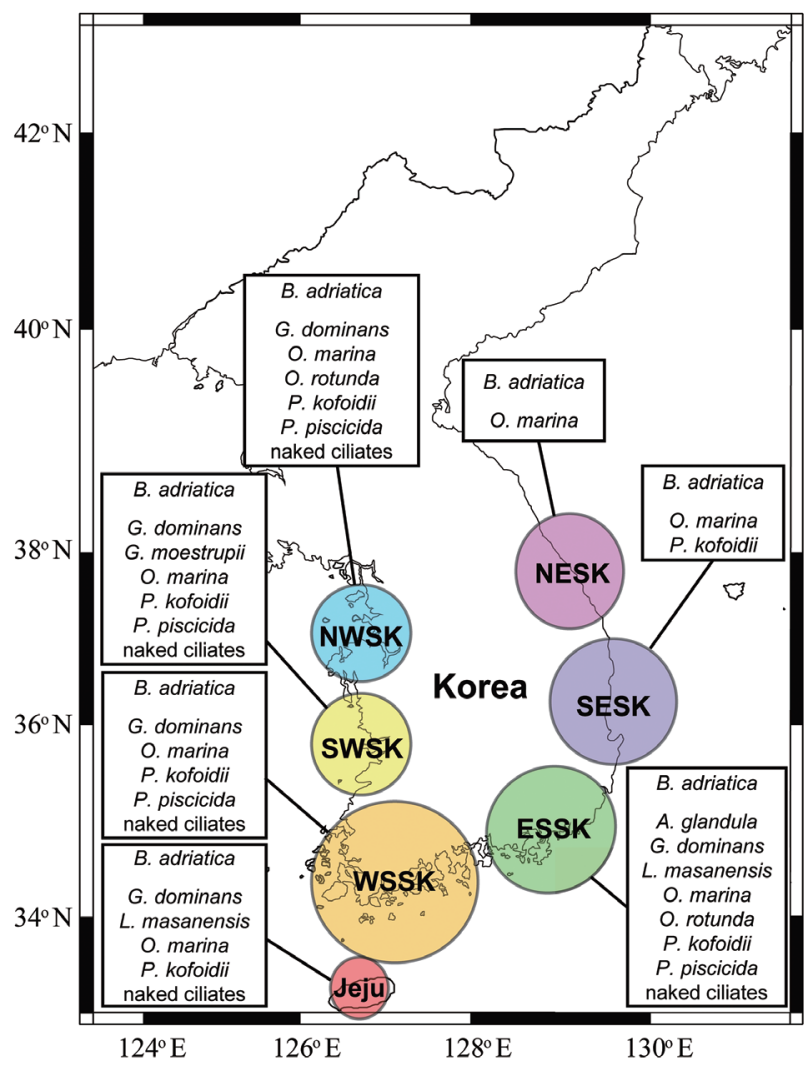

Fig. 6. Distributions of Biecheleriopsis adriatica and the heterotrophic protistan predators in Korean coastal waters. NWSK, northern West Sea of Korea; SWSK, southern West Sea of Korea; ESSK, eastern South Sea of Korea; WSSK, western South Sea of Korea; NESK, northern East Sea of Korea; SESK, southern East Sea of Korea. Data were obtained from our unpublished data, Jeong et al. (2001b, 2002, 2003, 2006, 2008a, 2011, 2017b), Kim and Lee (2003), Kim and Jeong (2004), Mason et al. (2007), Kang et al. (2013, 2019), Potvin et al. (2013), Yoo et al. (2013a), Affan et al. (2014), Lim et al. (2017b), Ok et al. (2017), Yoon (2017, 2018). B. adriatica, Biecheleriopsis adriatica; A. glandula, Aduncodinium glandula, G. dominans, Gyrodinium dominans, L. masanensis, Luciella masanensis; O. marina, Oxyrrhis marina; O. rotunda, Oblea rotunda; P. kofoidii, Polykrikos kofoidii; P. piscicida, Pfiesteria piscicida.

2019). This abundance is also lower than the threshold prey concentration for the growth of $O$. marina feeding on B. adriatica. Vegetative cells of B. adriatica have been found in the East, West, and South Seas of Korea (Fig. 6). Cells of $O$. marina have also been found in the East, West, and South Seas of Korea (Fig. 6). Thus, there is a high possibility that $O$. marina encounter and feed on $B$. adriatica in these waters. However, O. marina may not be abundant when B. adriatica co-occurs in Korean waters due to its abundances being lower than the threshold prey concentration for growth. Furthermore, G. dominans and $P$. kofoidii have been found in Korean waters in all four sea- sons (Jeong et al. 2002, Kang et al. 2013, Yoo et al. 2013a, Lim et al. 2017b). Thus, there is also a high possibility that these predators encounter and feed on B. adriatica. However, G. dominans and P. kofoidii did not grow on B. adriatica in this study; these common heterotrophic protists may not be abundant as the same time that $B$. adriatica co-occurs in these waters.

In conclusion, the combination of the results, such as the lower $\mu_{\max }$ or $\mathrm{I}_{\max }$ of O. marina on B. adriatica BATY06 than those on other prey species in the order Suessiales and most phototrophic prey species in the other orders; higher threshold prey concentration for the growth of $O$. marina feeding on $B$. adriatica than the highest reported abundance of B. adriatica; and no growth of $G$. dominans, O. rotunda, P. kofoidii, and Strombidinopsis sp. on B. adriatica, suggests that B. adriatica may have an advantage over other competing prey species regarding their survival in marine environments.

\section{ACKNOWLEDGEMENTS}

We thank Sung Yeon Lee, An Suk Lim, and Sang Ah Park for technical support. This research was supported by the Useful Dinoflagellate program of Korea Institute of Marine Science and Technology Promotion (KIMST) funded by the Ministry of Oceans and Fisheries (MOF) and Development of the methods for controlling and managing marine ecological disturbance causing and harmful organisms (MEDHO) funded by the Ministry of Oceans and Fisheries, the National Research Foundation (NRF) funded by the Ministry of Science and ICT (NRF-2015M1A5A1041806; NRF-2017R1E1A1A01074419) award to HJJ.

\section{REFERENCES}

Adolf, J. E., Bachvaroff, T. R., Deeds, J. R. \& Place, A. R. 2015. Ichthyotoxic Karlodinium veneficum (Ballantine) J Larsen in the upper Swan River estuary (western Australia): ecological conditions leading to a fish kill. Harmful Algae 48:83-93.

Adolf, J. E., Krupatkina, D., Bachvaroff, T. \& Place, A. R. 2007. Karlotoxin mediates grazing by Oxyrrhis marina on strains of Karlodinium veneficum. Harmful Algae 6:400412.

Affan, M. A., Lee, J. B., Khomayis, H. S., Touliabah, H. E. S. \& Abdulwassi, N. I. 2014. Community composition and dynamics of phytoplankton at the western coast of Jeju 
Island, Korea. Indian J. Geo-Mar. Sci. 43:1879-1890.

Benico, G. A., Takahashi, K., Lum, W. M., Yñiguez, A. T., Azanza, R. V., Leong, S. C. Y., Lim, P. T. \& Iwataki, M. 2019. First report of Biecheleriopsis adriatica in Bolinao, Northwestern Philippines and its wide distribution in Southeast Asia and adjacent waters. Philipp. J. Nat. Sci. 24:34-41.

Calbet, A., Isari, S., Martínez, R. A., Saiz, E., Garrido, S., Peters, J., Borrat, R. M. \& Alcaraz, M. 2013. Adaptations to feast and famine in different strains of the marine heterotrophic dinoflagellates Gyrodinium dominans and Oxyrrhis marina. Mar. Ecol. Prog. Ser. 483:67-84.

Calbet, A. \& Landry, M. R. 2004. Phytoplankton growth, microzooplankton grazing, and carbon cycling in marine systems. Limnol. Oceanogr. 49:51-57.

Carlsson, P., Granéli, E. \& Segatto, A. Z. 1999. Cycling of biologically available nitrogen in riverine humic substances between marine bacteria, a heterotrophic nanoflagellate and a photosynthetic dinoflagellate. Aquat. Microb. Ecol. 18:23-36.

Claessens, M., Wickham, S. A., Post, A. F. \& Reuter, M. 2008. Ciliate community in the oligotrophic Gulf of Aqaba, Red Sea. Aquat. Microb. Ecol. 53:181-190.

Coats, D. W. 1999. Parasitic life styles of marine dinoflagellates. J. Eukaryot. Microbiol. 46:402-409.

Eppley, R. W., Renger, E. H., Venrick, E. L. \& Mullin, M. M. 1973. A study of plankton dynamics and nutrient cycling in the central gyre of the north pacific ocean. Limnol. Oceanogr. 18:534-551.

Frost, B. W. 1972. Effects of size and concentration of food particles on the feeding behavior of the marine planktonic copepod Calanus pacificus. Limnol. Oceanogr. 17:805-815.

Fuller, A. K. R. 1990. The grazing and growth rates of some marine protozoa measured in batch and continuous culture with particular reference to the heterotrophic dinoflagellate Oxyrrhis marina. Ph. D. dissertation, Royal Holloway, University of London, Egham, pp. 57-129.

Hansen, P. J. 1992. Prey size selection, feeding rates and growth dynamics of heterotrophic dinoflagellates with special emphasis on Gyrodinium spirale. Mar. Biol. 114:327-334.

Hansen, P. J. 2011. The role of photosynthesis and food uptake for the growth of marine mixotrophic dinoflagellates. J. Eukaryot. Microbiol. 58:203-214.

Heinbokel, J. F. 1978. Studies on the functional role of tintinnids in the Southern California Bight. I. grazing and growth rates in laboratory cultures. Mar. Biol. 47:177189.

Jang, S. H., Jeong, H. J., Kwon, J. E. \& Lee, K. H. 2017. Mixot- rophy in the newly described dinoflagellate Yihiella yeosuensis: a small, fast dinoflagellate predator that grows mixotrophically, but not autotrophically. Harmful Algae 62:94-103.

Jang, S. H., Jeong, H. J., Lim, A. S., Kwon, J. E. \& Kang, N. S. 2016. Feeding by the newly described heterotrophic dinoflagellate Aduncodinium glandula: having the most diverse prey species in the family Pfiesteriaceae. Algae 31:17-31.

Jang, S. H., Jeong, H. J., Moestrup, Ø., Kang, N. S., Lee, S. Y., Lee, K. H., Lee, M. J. \& Noh, J. H. 2015. Morphological, molecular and ecophysiological characterization of the phototrophic dinoflagellate Biecheleriopsis adriatica from Korean coastal waters. Eur. J. Phycol. 50:301-317.

Jeong, H. J. 1999. The ecological roles of heterotrophic dinoflagellates in marine planktonic community. J. Eukaryot. Microbiol. 46:390-396.

Jeong, H. J., Ha, J. H., Park, J. Y., Kim, J. H., Kang, N. S., Kim, S., Kim, J. S., Yoo, Y. D. \& Yih, W. H. 2006. Distribution of the heterotrophic dinoflagellate Pfiesteria piscicida in Korean waters and its consumption of mixotrophic dinoflagellates, raphidophytes and fish blood cells. Aquat. Microb. Ecol. 44:263-278.

Jeong, H. J., Kang, H., Shim, J. H., Park, J. K., Kim, J. S., Song, J. Y. \& Choi, H. -J. 2001a. Interactions among the toxic dinoflagellate Amphidinium carterae, the heterotrophic dinoflagellate Oxyrrhis marina, and the calanoid copepods Acartia spp. Mar. Ecol. Prog. Ser. 218:77-86.

Jeong, H. J., Kang, H. C., You, J. H. \& Jang, S. H. 2018a. Interactions between the newly described small- and fast-swimming mixotrophic dinoflagellate Yihiella yeosuensis and common heterotrophic protists. J. Eukaryot. Microbiol. 65:612-626.

Jeong, H. J., Kim, J. S., Lee, K. H., Seong, K. A., Yoo, Y. D., Kang, N. S., Kim, T. H., Song, J. Y. \& Kwon, J. E. 2017a. Differential interactions between the nematocyst-bearing mixotrophic dinoflagellate Paragymnodinium shiwhaense and common heterotrophic protists and copepods: killer or prey. Harmful Algae 62:37-51.

Jeong, H. J., Kim, J. S., Song, J. Y., Kim, J. H., Kim, T. H., Kim, S. K. \& Kang, N. S. 2007. Feeding by heterotrophic protists and copepods on the heterotrophic dinoflagellates $P f i$ esteria pisicicida, Stoeckeria algicida, and Luciella masanensis. Mar. Ecol. Prog. Ser. 349:199-211.

Jeong, H. J., Kim, J. S., Yoo, Y. D., Kim, S. T., Kim, T. H., Park, M. G., Lee, C. H., Seong, K. A., Kang, N. S. \& Shim, J. H. 2003. Feeding by the heterotrophic dinoflagellate Oxyrrhis marina on the red-tide raphidophyte Heterosigma akashiwo: a potential biological method to control red tides using mass-cultured grazers. J. Eukaryot. Micro- 
biol. 50:274-282.

Jeong, H. J., Kim, J. S., Yoo, Y. D., Kim, S. T., Song, J. Y., Kim, T. H., Seong, K. A., Kang, N. S., Kim, M. S., Kim, J. H., Kim, S., Ryu, J., Lee, H. M. \& Yih, W. H. 2008a. Control of the harmful alga Cochlodinium polykrikoides by the naked ciliate Strombidinopsis jeokjo in mesocosm enclosures. Harmful Algae 7:368-377.

Jeong, H. J., Kim, S. K., Kim, J. S., Kim, S. T., Yoo, Y. D. \& Yoon, J. Y. 2001b. Growth and grazing rates of the heterotrophic dinoflagellate Polykrikos kofoidii on red-tide and toxic dinoflagellates. J. Eukaryot. Microbiol. 48:298-308.

Jeong, H. J., Kim, T. H., Yoo, Y. D., Yoon, E. Y., Kim, J. S., Seong, K. A., Kim, K. Y. \& Park, J. Y. 2011. Grazing impact of heterotrophic dinoflagellates and ciliates on common redtide euglenophyte Eutreptiella gymnastica in Masan Bay, Korea. Harmful Algae 10:576-588.

Jeong, H. J., Lee, C. W., Yih, W. H. \& Kim, J. S. 1997. Fragilidium $\mathrm{cf}$. mexicanum, a thecate mixotrophic dinoflagellate which is prey for and a predator on co-occurring thecate heterotrophic dinoflagellate Protoperidinium cf. divergens. Mar. Ecol. Prog. Ser. 151:299-305.

Jeong, H. J., Lim, A. S., Franks, P. J. S., Lee, K. H., Kim, J. H., Kang, N. S., Lee, M. J., Jang, S. H., Lee, S. Y., Yoon, E. Y., Park, J. Y., Yoo, Y. D., Seong, K. A., Kwon, J. E. \& Jang, T. Y. 2015. A hierarchy of conceptual models of red-tide generation: nutrition, behavior, and biological interactions. Harmful Algae 47:97-115.

Jeong, H. J., Lim, A. S., Lee, K., Lee, M. J., Seong, K. A., Kang, N. S., Jang, S. H., Lee, K. H., Lee, S. Y., Kim, M. O., Kim, J. H., Kwon, J. E., Kang, H. C., Kim, J. S., Yih, W., Shin, K., Jang, P. K., Ryu, J. -H., Kim, S. Y., Park, J. Y. \& Kim, K. W. 2017b. Ichthyotoxic Cochlodinium polykrikoides red tides offshore in the South Sea, Korea in 2014: I. temporal variations in three-dimensional distributions of red-tide organisms and environmental factors. Algae 32:101-130.

Jeong, H. J., Lim, A. S., Yoo, Y. D., Lee, M. J., Lee, K. H., Jang, T. Y. \& Lee, K. 2014. Feeding by heterotrophic dinoflagellates and ciliates on the free-living dinoflagellate Symbiodinium sp.(Clade E). J. Eukaryot. Microb. 61:27-41.

Jeong, H. J., Seong, K. A., Yoo, Y. D., Kim, T. H., Kang, N. S., Kim, S., Park, J. Y., Kim, J. S., Kim, G. H. \& Song, J. Y. $2008 \mathrm{~b}$. Feeding and grazing impact by small marine heterotrophic dinoflagellates on hetertrophic bacteria. J. Eukaryot. Microbiol. 55:271-288.

Jeong, H. J., Shim, J. H., Lee, C. W., Kim, J. S. \& Koh, S. M. 1999. Growth and grazing rates of the marine planktonic ciliate Strombidinopsis sp. on red-tide and toxic dinoflagellates. J. Eukaryot. Microbiol.46:69-76.

Jeong, H. J., Yoo, Y. D. \& Kim, J. S. 2002. Outbreak of red tides in the coastal waters off the Southern Saemankeum areas, Jeonbuk, Korea 2. Temporal variation in the heterotrophic dinoflagellates and ciliates in the summer-fall of 1999. J. Korean Soc. Oceanogr. 7:140-147. (in Korean with English abstract)

Jeong, H. J., Yoo, Y. D., Kim, J. S., Seong, K. A., Kang, N. S. \& Kim, T. H. 2010. Growth, feeding, and ecological roles of the mixotrophic and heterotrophic dinoflagellates in marine planktonic food webs. Ocean Sci. J. 45:65-91.

Jeong, H. J., You, J. H., Lee, K. H., Kim, S. J. \& Lee, S. Y. $2018 b$. Feeding by common heterotrophic protists on the mixotrophic alga Gymnodinium smaydae (Dinophyceae), one of the fastest growing dinoflagellates. J. Phycol. 54:734-743.

Johnson, M. D. 2015. Inducible mixotrophy in the dinoflagellate Prorocentrum minimum. J. Eukaryot. Microbiol. 62:431-443.

Kang, H. C., Jeong, H. J., Kim, S. J., You, J. H. \& Ok, J. H. 2018. Differential feeding by common heterotrophic protists on 12 different Alexandrium species. Harmful Algae 78:106-117.

Kang, H. C., Jeong, H. J., Ok, J. H., You, J. H., Jang, S. H., Lee, S. Y., Lee, K. H., Park, J. Y. \& Rho, J-R. 2019. Spatial and seasonal distributions of the phototrophic dinoflagellate Biecheleriopsis adriatica (Suessiaceae) in Korea: quantification using qPCR. Algae 34:111-126.

Kang, N. S., Jeong, H. J., Yoo, Y. D., Yoon, E. Y., Lee, K. H., Lee, K. \& Kim, G. 2011. Mixotrophy in the newly described phototrophic dinoflagellate Woloszynskia cincta from western Korean waters: feeding mechanism, prey species and effect of prey concentration. J. Eukaryot. Microbiol. 58:152-170.

Kang, N. S., Lee, K. H., Jeong, H. J., Yoo, Y. D., Seong, K. A., Potvin, E., Hwang, Y. J. \& Yoon, E. Y. 2013. Red tides in Shiwha Bay, western Korea: a huge dike and tidal power plant established in a semi-enclosed embayment system. Harmful Algae 30(Suppl. 1):S114-S130.

Kim, J. S. \& Jeong, H. J. 2004. Feeding by the heterotrophic dinoflagellates Gyrodinium dominans and G. spirale on the red-tide dinoflagellate Prorocentrum minimum. Mar. Ecol. Prog. Ser. 280:85-94.

Kim, S. J., Jeong, H. J., Kang, H. C., You, J. H. \& Ok, J. H. 2019. Differential feeding by common heterotrophic protists on four Scrippsiella species of similar size. J. Phycol. doi:10.1111/jpy.12864.

Kim, Y. H. \& Lee, J. B. 2003. Seasonal variations and species composition of planktonic ciliates in the southern coastal waters of Jeju Island, Korea. J. Korean Soc. Oceanogr. 8:59-69. (in Korean with English abstract)

Kimmance, S. A., Atkinson, D. \& Montagnes, D. J. S. 2006. 
Do temperature-food interactions matter? Responses of production and its components in the model heterotrophic flagellate Oxyrrhis marina. Aquat. Microb. Ecol. 42:63-73.

Lessard, E. J. 1984. Oceanic heterotrophic dinoflagellates: distribution, abundance, and role as microzooplankton. Ph.D. dissertation, University of Rhode Island, Kingston, RI, $166 \mathrm{pp}$.

Levinsen, H. \& Nielsen, T. G. 2002. The trophic role of marine pelagic ciliates and heterotrophic dinoflagellates in arctic and temperate coastal ecosystems: a cross-latitude comparison. Limnol. Oceanogr. 47:427-439.

Lim, A. S., Jeong, H. J., Kim, J. H. \& Lee, S. Y. 2017a. Control of ichthyotoxic Cochlodinium polykrikoides using the mixotrophic dinoflagellate Alexandrium pohangense: a potential effective sustainable method. Harmful Algae 63:109-118.

Lim, A. S., Jeong, H. J., Seong, K. A., Lee, M. J., Kang, N. S., Jang, S. H., Lee, K. H., Park, J. Y., Jang, T. Y. \& Yoo, Y. D. 2017b. Ichthyotoxic Cochlodinium polykrikoides red tides offshore in the South Sea, Korea in 2014: II. Heterotrophic protists and their grazing impacts on redtide organisms. Algae 32:199-222.

Lindberg, K., Moestrup, Ø. \& Daugbjerg, N. 2005. Studies on woloszynskioid dinoflagellates I: Woloszynskia coronata re-examined using light and electron microscopy and partial LSU rDNA sequences, with description of Tovellia gen. nov. and Jadwigia gen. nov. (Tovelliaceae fam. nov.). Phycologia 44:416-440.

Mason, P. L., Litaker, R. W., Jeong, H. J., Ha, J. H., Reece, K. S., Stokes, N. A., Park, J. Y., Steidinger, K. A., Vandersea, M. W., Kibler, S., Tester, P. A. \& Vogelbein, W. K. 2007. Description of a new genus Pfiesteria-like dinoflagellate, Luciella gen. nov. (Dinophyceae), including two new species: Luciella masanensis sp. nov. and Luciella atlantis sp. nov. J. Phycol. 43:799-810.

Menden-Deuer, S. \& Lessard, E. J. 2000. Carbon to volume relationships for dinoflagellates, diatoms, and other protist plankton. Limnol. Oceanogr. 45:569-579.

Menden-Deuer, S., Lessard, E. J., Satterberg, J. \& Grünbaum, D. 2005. Growth rates and starvation survival of three species of the pallium-feeding, thecate dinoflagellate genus Protoperidinium. Aquat. Microb. Ecol. 41:145152.

Menden-Deuer, S. \& Montalbano, A. L. 2015. Bloom formation potential in the harmful dinoflagellate Akashiwo sanguinea: clues from movement behaviors and growth characteristics. Harmful Algae 47:75-85.

Moestrup, Ø., Lindberg, K. \& Daugbjerg, N. 2009. Studies on woloszynskioid dinoflagellates V. Ultrastructure of
Biecheleriopsis gen. nov., with description of Biecheleriopsis adriatica sp. nov. Phycol. Res. 57:221-237.

Montagnes, D. J. S. \& Lessard, E. J. 1999. Population dynamics of the marine planktonic ciliate Strombidinopsis multiauris: its potential to control phytoplankton blooms. Aquat. Microb. Ecol. 20:167-181.

Ok, J. H., Jeong, H. J., Lim, A. S. \& Lee, K. H. 2017. Interactions between the mixotrophic dinoflagellate Takayama helix and common heterotrophic protists. Harmful Algae 68:178-191.

Potvin, É., Hwang, Y. J., Yoo, Y. D., Kim, J. S. \& Jeong, H. J. 2013. Feeding by heterotrophic protists and copepods on the photosynthetic dinoflagellate Azadinium cf. poporum from western Korean waters. Aquat. Microb. Ecol. 68:143-158.

Sherr, E. B. \& Sherr, B. F. 2002. Significance of predation by protists in aquatic microbial food webs. Antonie Van Leeuwenhoek 81:293-308.

Stoecker, D. K. 1999. Mixotrophy among dinoflagellates. J. Eukaryot. Microbiol. 46:397-401.

Stoecker, D. K., Hansen, P. J., Caron, D. A. \& Mitra, A. 2017. Mixotrophy in the marine plankton. Annu. Rev. Mar. Sci. 9:311-335.

Strom, S. L. \& Buskey, E. J. 1993. Feeding, growth, and behavior of the thecate heterotrophic dinoflagellate Oblea rotunda. Limnol. Oceanogr. 38:965-977.

Strom, S. L. \& Morello, T. A. 1998. Comparative growth rates and yields of ciliates and heterotrophic dinoflagellates. J. Plankton Res. 20:571-584.

Strom, S., Wolfe, G., Holmes, J., Stecher, H., Shimeneck, C. \& Sarah, L. 2003. Chemical defense in the microplankton I: feeding and growth rates of heterotrophic protists on the DMS-producing phytoplankter Emiliania huxleyi. Limnol. Oceanogr. 48:217-229.

Taylor, F. J. R., Hoppenrath, M. \& Saldarriaga, J. F. 2008. Dinoflagellate diversity and distribution. Biodivers. Conserv. 17:407-418.

Tillmann, U. 2004. Interactions between planktonic microalgae and protozoan grazers. J. Eukaryot. Microbiol. 51:156-168.

Tillmann, U. \& Hoppenrath, M. 2013. Life cycle of the pseudocolonial dinoflagellate Polykrikos kofoidii (Gymnodiniales, Dinoflagellata). J. Phycol. 49:298-317.

Tillmann, U. \& Reckermann, M. 2002. Dinoflagellate grazing on the raphidophyte Fibrocapsa japonica. Aquat. Microb. Ecol. 26:247-257.

Turner, J. T. \& Borkman, D. G. 2005. Impact of zooplankton grazing on Alexandrium blooms in the offshore Gulf of Maine. Deep Sea Res. Part 2 Top. Stud. Oceanogr. 52:2801-2816. 
Watts, P. C., Martin, L. E., Kimmance, S. A., Montagnes, D. J. S. \& Lowe, C. D. 2010. The distribution of Oxyrrhis mari$n a$ : a global disperser or poorly characterized endemic? J. Plankton Res. 33:579-589.

Yoo, Y. D., Jeong, H. J., Kang, N. S., Kim, J. S., Kim, T. H. \& Yoon, E. Y. 2010. Ecology of Gymnodinium aureolum. II. predation by common heterotrophic dinoflagellates and a ciliate. Aquat. Microb. Ecol. 59:257-272.

Yoo, Y. D., Jeong, H. J., Kim, J. S., Kim, T. H., Kim, J. H., Seong, K. A., Lee, S. H., Kang, N. S., Park, J. W., Park, J., Yoon, E. Y. \& Yih, W. H. 2013a. Red tides in Masan Bay, Korea in 2004-2005: II. daily variations in the abundance of heterotrophic protists and their grazing impact on red-tide organisms. Harmful Algae 30(Suppl. 1):S89-S101.

Yoo, Y. D., Yoon, E. Y., Jeong, H. J., Lee, K. H., Hwang, Y. J., Seong, K. A., Kim, J. S. \& Park, J. Y. 2013b. The newly de- scribed heterotrophic dinoflagellate Gyrodinium moestrupii, an effective protistan grazer of toxic dinoflagellate. J. Eukaryot. Microbiol. 60:13-24.

Yoo, Y. D., Yoon, E. Y., Lee, K. H., Kang, N. S. \& Jeong, H. J. 2013c. Growth and ingestion rates of heterotrophic dinoflagellates and a ciliate on the mixotrophic dinoflagellate Biecheleria cincta. Algae 28:343-354.

Yoon, E. Y. 2018. The heterotrophic dinoflagellates Oxyrrhis marina and Oxyrrhis maritima in Korean waters: taxonomy, physiology, distribution, and production of useful materials. Ph.D. dissertation, Seoul National University, Seoul, 133 pp.

Yoon, Y. H. 2017. Marine bio-environmental characteristics with the distributions of dinoflagellate cyst assemblages in the Ulsan coastal waters (UCW). Korean J. Environ. Biol. 35:361-372. (in Korean with English abstract) 